\title{
Sistem Pakar Dalam Mengidentifikasi Jenis Kerusakan Mesin Pada Mobil Suzuki Carry Berbasis Web
}

\author{
A. F. Arbie ${ }^{(1)}$, Ir. H. F. Wowor, M.Kom. ${ }^{(2)}$, J. R. Robot, ST., MTI. ${ }^{(3)}$, R. Sengkey, ST., MT. ${ }^{(4)}$ \\ angga_arbie@ rocketmail.com @gmail.com ${ }^{(1)}$ hans.wowor@unsrat.ac.id ${ }^{(2)}$ \\ jimmy.robot@unsrat.ac.id ${ }^{(3)}$ rizal.sengkey@unsrat.ac.id ${ }^{(4}$
}

Fakultas Teknik, Universitas Sam Ratulangi Manado-95115

\begin{abstract}
Growing technology in the field of cars as well as the more expensive new cars sold by each automaker. It makes people switch to buy old cars. The conditions of new and used cars are very different. When the new car is only doing engine maintenance each month with an oil change or other types of treatment, while an did car should check the condition of the engine every month. If there is a damage to this cars, the costs to enter the workshop is more higher then new cars. Because of the high cost if the car into the workshop, then the old cars owner must think to look for the other alternatives in repairing damage to the engine.
\end{abstract}

According to identify the type of Expert System for Damage Engine In Car Suzuki Carry based on a Web-based tools to diagnose the type of damage to the engine Suzuki Carry and provide solutions in repairing the damage. The interaction between the system and the user uses the question of the causes that have appeared on the perceived condition of the driver and the performance of the car which the user will be asked to answer questions based on the condition of the car. Knowledge base is structured in such a database table, it is a table with some damage, the cause of the table and the table relationships to facilitate the performance of the inference system.

Keyword : Expert System, Damage Diagnosis, Web-based

\footnotetext{
Abstrak

Dengan semakin berkembangnya teknologi dalam bidang mobil serta semakin mahalnya mobil baru yang dijual oleh tiap produsen mobil. Membuat banyak orang beralih untuk membeli mobil dalam keadaan bekas. Tentu kondisi antara mobil baru dan bekas sangat berbeda. Bila mobil baru hanya melakukan perawatan mesin setiap bulannya dengan mengganti oli atau jenis perawatan lainnya, maka untuk mobil bekas harus mengecek kondisi mesin setiap bulannya. Bila terjadi kerusakan maka biaya yang dikeluarkan untuk masuk bengkel juga sangat besar dalam memperbaikinya. Dengan biaya yang mahal bila mobil masuk bengkel, maka pemilik mobil bekas pasti berpikir untuk mencari alternatif lain dalam memperbaiki kerusakan mesin mobil.

Sistem Pakar Dalam Mengidentifikasi Jenis Kerusakan Mesin Pada Mobil Suzuki Carry Berbasis Web dirancang sebagai alat bantu untuk mendiagnosa jenis kerusakan mesin Suzuki carry serta memberikan solusi dalam memperbaiki kerusakan. Interaksi antara sistem dan user menggunakan pertanyaan berupa penyebab yang sudah tampak berdasarkan kondisi yang dirasakan pengemudi dan kinerja dari mobil dimana user akan
}

Basis pengetahuan disusun sedemikian rupa ke dalam suatu database diantaranya dengan beberapa tabel yaitu tabel kerusakan, tabel penyebab dan tabel relasi untuk mempermudah kinerja sistem dalam penarikan kesimpulan.

Kata kunci : Sistem Pakar, Diagnosa Kerusakan, Berbasis Web

\section{PENDAHULUAN}

Perkembangan komputer dewasa ini telah mengalami banyak perubahan yang sangat pesat, seiring dengan kebutuhan manusia yang semakin banyak dan kompleks. Hal ini mendorong para ahli untuk semakin mengembangkan komputer agar dapat membantu kerja manusia atau bahkan melebihi kemampuan kerja manusia. Begitu juga dengan aplikasi-aplikasi atau program-program yang dibuat dalam rangka membantu atau mempermudah manusia dalam bekerja.

Kecerdasan buatan atau artificial intelligence (AI) Kecerdasan buatan atau artificial intelligence (AI) adalah ide - ide untuk membuat suatu perangkat lunak computer yang memiliki kecerdasan sehingga perangkat lunak komputer tersebut dapat melakukan suatu pekerjaan yang dilakukan oleh manusia (Artanti, 2004). Aktifitas manusia yang dapat ditirukan seperti penalaran, penglihatan, pembelajaran, pemecahan masalah, pemahaman bahasa alami dan sebagainya. Sesuai dengan definisi tersebut, maka teknologi kecerdasan buatan dipelajari dalam bidang - bidang seperti : Robotika (Robotics), Penglihatan komputer (Computer Vision), Pengolahan bahasa alami (Natural Language Processing), Pengenalan pola (Pattern Recognition), Sistem Syaraf Buatan (Artificial Neural System), Pengenalan Suara (Speech Recognition), dan Sistem Pakar (Expert System). Sistem Pakar (Expert System) adalah program berbasis pengetahuan yang menyediakan solusi-solusi untuk problema-problema dengan kualitas pakar. Sistem pakar merupakan program komputer yang meniru proses pemikiran dan pengetahuan pakar dalam menyelesaikan suatu masalah tertentu. Sistem pakar dibangun untuk mencoba menyerupai kemampuan manusia dalam menyelesaikan masalah tertentu dalam bentuk heuristik. Implementasi dari sistem pakar juga dapat diterapkan di segala bidang, termasuk di bidang kerusakan mesin mobil (Broto, 2010).

Dengan semakin berkembangnya teknologi dalam bidang mobil serta semakin mahalnya mobil baru 
yang dijual oleh tiap produsen mobil dan dengan keadaan ekonomi yang mengalami krisis. Membuat banyak orang beralih untuk membeli mobil dalam keadaan bekas. Tentu kondisi antara mobil baru dan bekas sangat berbeda. Bila mobil baru hanya melakukan perawatan mesin setiap bulannya dengan mengganti oli atau jenis perawatan lainnya, maka untuk mobil bekas harus mengecek kondisi mesin setiap bulannya. Bila terjadi kerusakan maka biaya yang dikeluarkan untuk masuk bengkel juga sangat besar dalam memperbaikinya. Dengan biaya yang mahal bila mobil masuk bengkel, maka pemilik mobil bekas pasti berpikir untuk mencari alternatif lain dalam memperbaiki kerusakan mesin mobil.

Untuk membantu mengoptimalisasi kerja dari pada manusia dalam memperbaiki mesin mobil dengan ini penulis mengambil judul "Sistem Pakar Dalam Mengidentifikasi Jenis Kerusakan Mesin Pada Mobil Suzuki Carry Berbasis Web".

\section{LANDASAN TEORI}

\section{A. Sistem Pakar}

Secara umum, Sistem pakar yang baik dirancang agar dapat menyelesaikan suatu permasalahan tertentu dengan meniru kerja dari para ahli. Dengan sistem pakar ini, orang awam pun dapat menyelesaikan dengan bantuan para ahli. Bagi para ahli, sistem pakar ini juga akan membantu aktivitasnya sebagai asisten yang sangat berpengalaman. Ada beberapa definisi tentang sistem pakar, antara lain Menurut Ignizio (1991) Sistem pakar adalah suatu model dan prosedur yang berkaitan, dalam suatu domain tertentu, yang mana tingkat keahliannya dapat dibandingkan dengan keahlian seorang pakar. Menurut Siswanto (2005) menjelaskan bahwa sistem pakar adalah program AI (Artificial Intelligence) dengan basis pengetahuan (knowledge base) yang diperoleh dari pengetahuan beberapa pakar atau ahli dalam memecahkan persoalan pada bidang tertentu dan didukung mesin inferensi (Inferensi Engine) yang melakukan penalaran atau pelacakan terhadap sesuatu atau fakta-fakta yang diberikan oleh User lalu dicocokan (Matching) dengan fakta-fakta dan aturan atau akidah yang ada dibasis pengetahuan setelah dilakukan pencarian, sehingga tercapai kesimpulan. Menurut Durkin (1994) Sistem pakar adalah suatu program komputer yang dirancang untuk memodelkan kemampuan penyelesaian masalah yang dilakukan oleh seorang sistem pakar.

\section{Ciri - cirri Sistem Pakar}

Seorang pakar adalah seseorang yang memiliki ciri - ciri sebagai berikut menurut (Kusrini, 2006):

1. Terbatas pada domain keahlian tertentu.

2. Dapat memberikan penalaran untuk data-data yang tidak pasti.

3. Dapat mengemukakan rangkaianalasan-alasan yang diberikannya dengan cara yang dapat dipahami.

4. Berdasarkan pada kaidah atau rule tertentu.

5. Dirancang untuk dikembangkan sacara bertahap.

6. Keluarannya atau output bersifat anjuran.
Sistem pakar adalah program komputer yang menirukan penalaran seorang pakar dengan keahlian pada suatu wilayah pengetahuan tertentu. Sistem pakar merupakan program "artificial inteligence" ("kecerdasan buatan" atau AI) yang menggabungkan basis pengetahuan dengan mesin inferensi. Ini merupakan bagian perangkat lunak spesialisasi tingkat tinggi atau bahasa pemrograman tingkat tinggi (High Level Language), yang berusaha menduplikasi fungsi seorang pakar dalam satu bidang keahlian tertentu. Program ini bertindak sebagai konsultan yang cerdas atau penasihat dalam suatu lingkungan keahlian tertentu, sebagai hasil himpunan pengetahuan yang telah dikumpulkan dari beberapa orang pakar (Broto, 2010).

Dengan demikian seorang awam sekalipun bisa menggunakan sistem pakar itu untuk memecahkan berbagai persoalan yang ia hadapi dan bagi seorang ahli, sistem pakar dapat dijadikan alat untuk menunjang aktivitasnya yaitu sebagai sebagai asisten yang berpengalaman. Sistem pakar yang muncul pertama kali adalah General-purpose problem solver (GPS) yang dikembangkan oleh Newl dan Simon. Sampai saat ini sudah banyak sistem pakar yang dibuat, seperti MYCIN, DENDRAL, XCON \& XSEL, SOPHIE, Prospector, FOLIO, DELTA,dan sebagainya (Broto, 2010).

\section{Keuntungan Dan Kelemahan Sistem Pakar}

2006):

Keuntungan sistem pakar menurut (Kusrini,

a) Memungkinkan orang awam dapat mengerjakan pekerjaan para ahli.

b) Dapat melakukan proses secara berulang secara otomatis.

c) Menyimpan pengetahuan dan keahlian para pakar.

d) Meningkatkan kualitas, dengan memberi nasehat yang konsisten dan mengurangi kesalahan.

e) Meningkatkan hasil dan produktivitas, karena sistem pakar dapat bekerja lebih cepat dari manusia.

f) Memiliki kemampuan untuk bekerja dengan informasi yang tidak lengkap dan mengandung ketidakpastian. 2006):

Kelemahan sistem pakar menurut (Kusrini,

a) Biaya yang diperlukan untuk membuat, memelihara, dan mengembangkannya sangat mahal.

b) Sulit dikembangkan, hal ini erat kaitannya dengan ketersediaan pakar di bidangnya.

c) Sistem pakar tidak $100 \%$ benar karena seseorang yang terlibat dalam pembuatan sistem pakar tidak selalu benar. Oleh karena itu perlu diuji ulang secara teliti sebelum digunakan.

d) Kepakaran sangat sulit diekstrak dari manusia.

e) Pendekatan oleh setiap pakar untuk suatu situasi atau problem bias berbeda-beda, meskipun samasama benar.

f) Sangat sulit bagi seorang pakar untuk mengabstraksi atau menjelaskan langkah mereka dalam menangani masalah. 


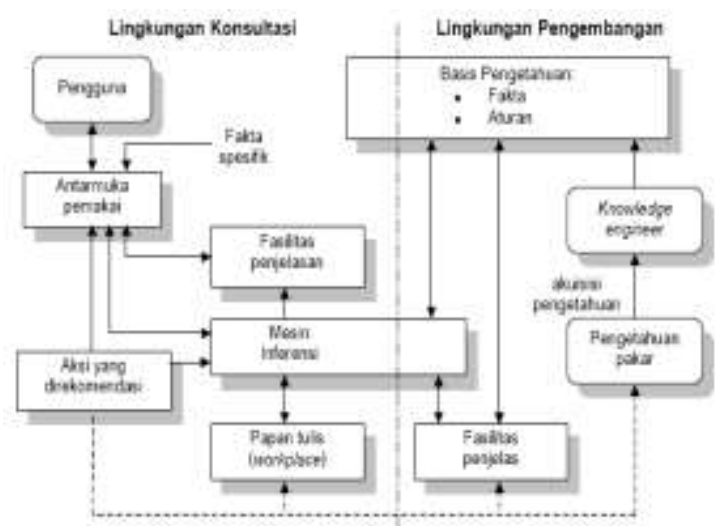

Gambar 1 Struktur Sistem Pakar

\section{Struktur Sistem Pakar.}

Sistem pakar memiliki dua bagian utama (Turban, 2005), seperti pada gambar 1, yaitu

1. Lingkungan pengembangan (development environment), yaitu bagian yang digunakan untuk memasukkan pengetahuan pakar ke dalam lingkungan sistem pakar.

2. Lingkungan konsultasi (consultation environment), yaitu bagian yang digunakan oleh pengguna yang bukan pakar untuk memperoleh pengetahuan

\section{B. HTML (Hypertext Markup Language)}

HTML merupakan file teks yang ditulis menggunakan aturan-aturan kode tertentu untuk kemudian disajikan ke pengguna melalui suatu aplikasi web browser. Setiap informasi yang tampil di web selalu dibuat menggunakan kode HTML. Pembuatan dokumen HTML tidak tergantung pada aplikasi tertentu, karena dapat dibuat menggunakan aplikasi teks editor Notepad (untuk lingkungan Windows), Emacs atau Vi Editor (Untuk lingkungan Linux), dan sebagainya.Suatu file teks akan dianggap sebagai dokumen HTML jika memiliki ekstensi “.htm” atau “.html”. (Raharjo, 2010, 286).

\section{Bahasa Pemrograman PHP (Personal Home Page)}

Sejak pertama, PHP tercipta secara praktis dalam pemikiran. PHP (Personal Home Page) ditemukan oleh seorang pengembang perangkat lunak independen bernama Rasmus Lerdorf yang membuatnya tahu cara agar banyak pengunjung dapat membaca artikel onlinenya. Bagaimanapun, Lerdorf tidak bermaksud untuk merancang sebuah bahasa baru, namun untuk menyelesaikan sebuah permasalahan yang belum ada solusinya.(Gilmore, 2010, 5). Nama PHP merupakan sebuah akronim rekursif yakni Hypertext Preprocessor.PHP sangat baik fiturnya dalam menangani formulir pada dokumen HTML. PHP juga dapat berkomunikasi dengan berbagai macam sistem basis data, yang dapat memberikan kemampuan bagi pengembang untuk menghasilkan web berbasis sistem basis data MYSQL. (Ballard, 2009, 189).

\section{Database MySQL}

MySQL tergolong sebagai DBMS (DataBase Management System). Perangkat lunak ini bermanfaat untuk mengelola data dengan cara yang sangat fleksibel dan cepat. Berikut adalah sejumlah aktivitas yang terkait dengan data yang didukung oleh perangkat lunak tersebut (Kadir, 2010).

- Menyimpan data kedalam table,

- Menghapus data dalam table,

- Mengubah data dalam table,

- Mengambil data yang tersimpan dalam table,

- Memungkinkan data untuk memilih data tertentu yang di ambil,

- $\quad$ Memungkinkan untuk melakukan pengaturan hak akses terhadap data.

MySQL banyak dipakai untuk kepentingan penanganan database kerena selain handal juga bersifat open source. Konsekuensi dari open source, perangkat lunak ini dapat dipakai oleh siapa saja tanpa membayar dan source code-nya bisa diunduh oleh siapa saja (Kadir, 2010).

\section{E. Spesifikasi Mesin}

Spesifikasi mesin untuk jenis Suzuki Carry yang menjadi objek pembuktian adalah sebagai berikut:

Carry 1.500

a) Engine:

1. Tipe G 16A 4-silinder SOHC-8

2. Katup Isi Langkah $1.590 \mathrm{cc}$

3. Diameter x Langkah $75 \times 90 \mathrm{~mm}$

4. Perbandingan Kompresi 8.9:1

5. Tenaga Maksimum (EEC net ) $80 / 5.000 \mathrm{HP} / \mathrm{rpm}$

6. Momen Puntir Maksimum (EEC net) $13,8 / 3.000$ $\mathrm{Kg}-\mathrm{m} / \mathrm{rpm}$

Carry 1.000

a) Engine:

1. Tipe F 10 A 4 - cylinder SOHC 8 - Valve

2. Katup Isi Langkah $970 \mathrm{cc}$

3. Diameter $x$ Langkah $65,5 \times 72 \mathrm{~mm}$

4. Perbandingan Kompresi 8.8:1

5. Tenaga Maksimum (EEC net ) 55,5/5.500 HP/rpm

6. Momen Puntir Maksimum (EEC net) 7,8/4.000 Kg$\mathrm{m} / \mathrm{rpm}$

7. Karburator

\section{METODOLOGI PENELITIAN}

\section{A. Tempat dan Waktu Penelitian}

Dalam pelaksanaan tugas akhir ini penulis mengambil tempat pada Ruang Laboratorium Sistem Komputer (LSK), Jurusan Teknik Elektro, Fakultas Teknik Universitas Sam Ratulangi (UNSRAT), dengan waktu antara April 2012 hingga Agustus 2012, penulis melakukan penelitian di PT. Sinar Galesong Putra Manado untuk memperoleh data-data guna penulisan tugas akhir ini. 


\section{B. Bahan dan Peralatan}

Dalam mengerjakan tugas akhir ini mulai dari mendesain sampai tahap pemrograman penulis menggunakan perlengkapan komputer sebagai media untuk menjalankan program. Secara lebih spesifik perlengkapan komputer beserta pendukung yang digunakan yaitu:

1. Spesifikasi komputer/laptop client yang digunakan yaitu:
a. Sistem operasi Windows 7 32-bit.
b. Processor Intel Core i3 $2.40 \mathrm{GHz}$
c. RAM DDR3 2 GB
d. Harddisk $500 \mathrm{~GB}$.

2. Perangkat lunak, yaitu:

a. Mozilla Firefox, berfungsi sebagai web browser

b. Apache, berfungsi sebagai web server

c. PHP, berfungsi sebagai script editor dan interface editor

d. MySQL, berfungsi sebagai database server

\section{Prosedur Penelitian}

Prosedur yang dilakukan dalam membuat Sistem Pakar berbasis web, yaitu:

1. Melakukan studi literatur dan mencari materi-materi yang berhubungan dengan sistem dan proses analisa.

2. Melakukan perancangan sistem pakar.

3. Melakukan wawancara dengan Pak Anton Kepala Teknisi PT. Sinar Galesong Putra Manado

4. Melakukan pembuatan sistem pakar.

5. Melakukan pengujian dari sistem pakar yang telah dibuat.

\section{Diagram Konteks}

Secara umum, rancangan sistem ditunjukkan oleh diagram konteks pada gambar 2 .

\section{DFD Level 0}

Diagram Level 0 atau dekomposisi dari sistem pada diagram konteks digambarkan pada gambar 3 .

Pada bagian ini nama, alamat, pekerjaan dan jenis kelamin, no. polisi, dimasukkan kemudian disimpan dalam database (temporary user). Kemudian pilih keluhan setelah itu, sistem akan memberikan pertanyaaan (yang diambil dari Tabel penyebab) beserta pilihan jawaban (ya atau tidak). Setelah dimasukkan, maka sistem akan mencocokkan hasil jawaban dari user dengan database (tabel relasi). Kemudian, sistem akan memberikan output hasil diagnosa berupa solusinya akan ditampilkan dan hasil diagnosa kerusakan mesin akan di disimpan dalam database (tabel analisa hasil).

2). Ketika form login ditampilkan, proses selanjutnya akan menampilkan username dan password, jika username dan password dimasukkan maka sistem akan mencocokkan dalam database (tabel admin). Jika tidak terdaftar maka ditampilkan peringatan kesalahan. Jika username dan password terdaftar maka akan ke proses selanjutnya.
3). Proses ini akan dijalankan apabila status administrator. Sistem akan menampilkan 3 proses yaitu proses kerusakan, proses penyebab penyebab, proses relasi. Proses tersebut dapat dijalankan ketika admin mengeksekusi ketiga proses diatas.

\section{DFD Level 1 Proses Diagnosa}

Diagram level 1 atau dekomposisi dari proses diagnosa digambarkan gambar 4 .

1). Dalam proses ini, user memilih proses diagnosa kerusakan kemudian sistem akan menampilkan proses input data berupa nama, alamat, pekerjaan dan jenis kelamin untuk proses daftar. Selanjutnya, data dari user akan disimpan dalam database (tabel temporari user). Selanjutnya sistem akan menjalankan proses keluhan.

2). Pada bagian ini, sistem menampilkan keluhan yang diambil dari database (tabel kerusakan) dan akan ditampilkan pada user. Dari bagian inilah kemudian proses konsultasi dilakukan.

3). Pada bagian ini, sistem menampilkan pertanyaan yang diambil dari database (tabel penyebab) dan akan ditampilkan pada user. Setelah itu proses ini akan menampung masukkan jawaban dari user. Proses hasil kemudian dieksekusi ketika pertanyaan yang ditampilkan telah selesai dijawab. Selanjutnya melalui bagian ini, proses hasil kemudian akan dipicu.

4). Proses ini mengolah jawaban dari user dan dicocokkan dengan kerusakan database (tabel relasi). Selanjutnya sistem menampilkan hasil analisa kerusakan, penyebab beserta solusi kepada user. Data hasil analisa kerusakan dari user akan disimpan dalam database (tabel analisa hasil).

\section{Diagram Level 1 Proses Manajemen Database} Sistem Pakar

Diagram level 1 atau dekomposisi dari proses manajemen database soal digambarkan gambar 5 .

1). Setelah proses login, Selanjutnya admin memilih proses kerusakan dan sistem akan menampilkan daftar tambah kerusakan, ubah dan hapus kerusakan. Jika admin memilih proses tambah kerusakan, sistem akan menampilkan form berupa kode dan nama kerusakan. Setelah admin menambah kode dan nama kerusakan yang baru maka sistem akan menampilkan hasil dari output kode dan nama kerusakan yang baru. Selanjutnya bila admin memilih proses hapus kerusakan maka sistem akan menampilkan hasil dari proses hapus yang admin lakukan. Dan jika admin memilih proses ubah, maka sistem akan menampilkan form berupa kode dan nama kerusakan yang ada untuk di ubah dan setelah admin melakukan proses perubahan pada kode dan nama kerusakan maka output dari hasil perubahan akan ditampilkan oleh sistem. 
2). Selanjutnya admin memilih proses penyebab dan sistem akan menampilkan daftar tambah penyebab, ubah, hapus. Jika admin memilih proses tambah penyebab maka sistem akan menampilkan form berupa kode, nama penyebab dan solusi. Setelah admin melakukan perubahan dengan memasukkan kode, nama penyebab dan solusi maka sistem akan menampilkan hasil output kode, nama penyebab dan solusi yang baru. Proses selanjutnya jika admin memilih proses hapus penyebab maka sistem akan menampilkan hasil dari proses hapus yang admin lakukan. Dan jika admin memilih proses ubah maka sistem akan menampilkan form kode, nama penyebab dan solusi. Setelah admin melakukan perubahan pada kode, nama penyebab dan solusi maka output dari hasil kode, nama penyebab dan solusi hasil perubahan akan ditampilkan oleh sistem.

3). Proses relasi ini dilakukan jika admin melakukan input penambahan kerusakan dan penyebab yang baru maka proses relasi dilakukan dengan menghubungan antara kerusakan dan penyebab. Selanjutnya hasil dari proses relasi yang dilakukan oleh admin akan ditampilkan oleh sistem.

4). Proses laporan ini dilakukan jika admin melakukan input pada proses manajemen penyebab. Selanjutnya hasil dari proses perubahan yang dilakukan oleh admin akan ditampilkan oleh sistem pada proses laporan.

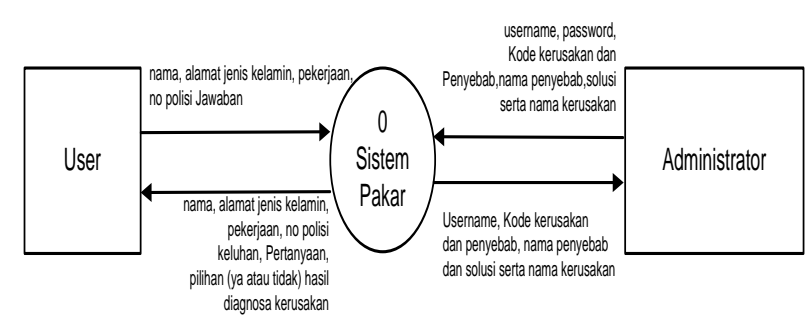

Gambar 2 Diagram Konteks.

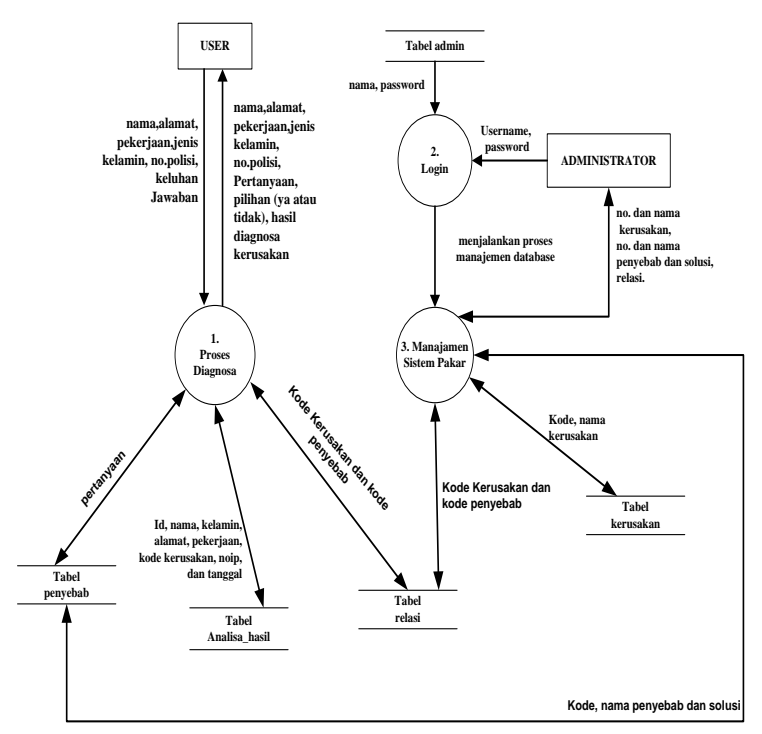

Gambar 3 Diagram Level 0

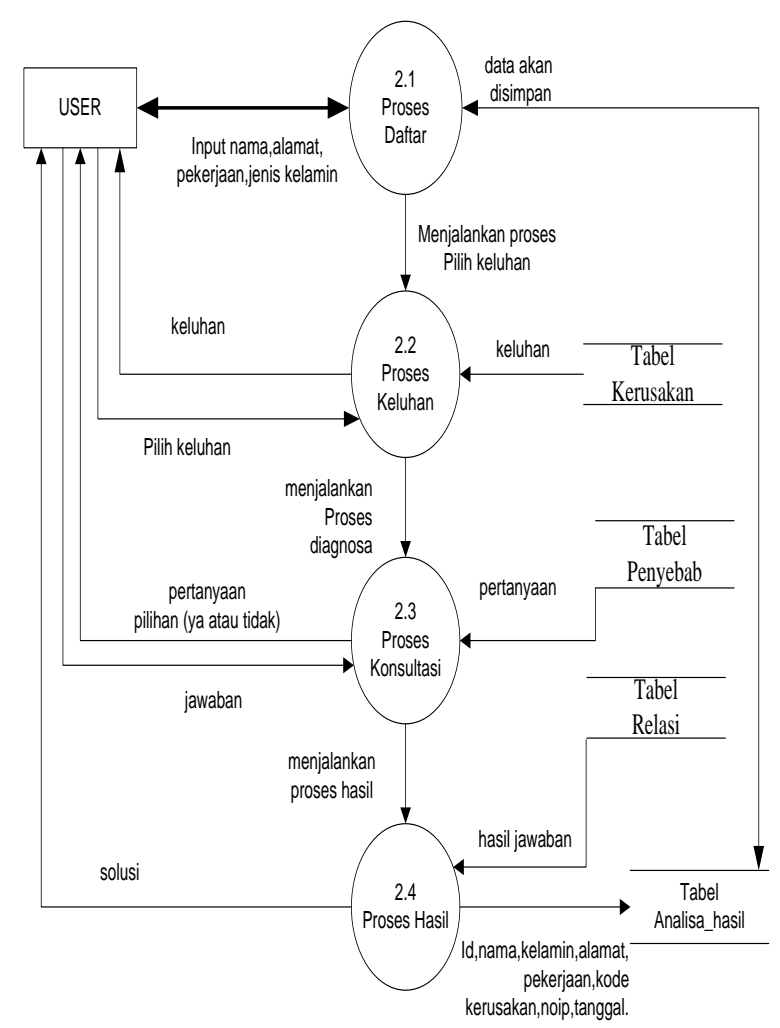

Gambar 4 Diagram Level 1 dari Proses Diagnosa

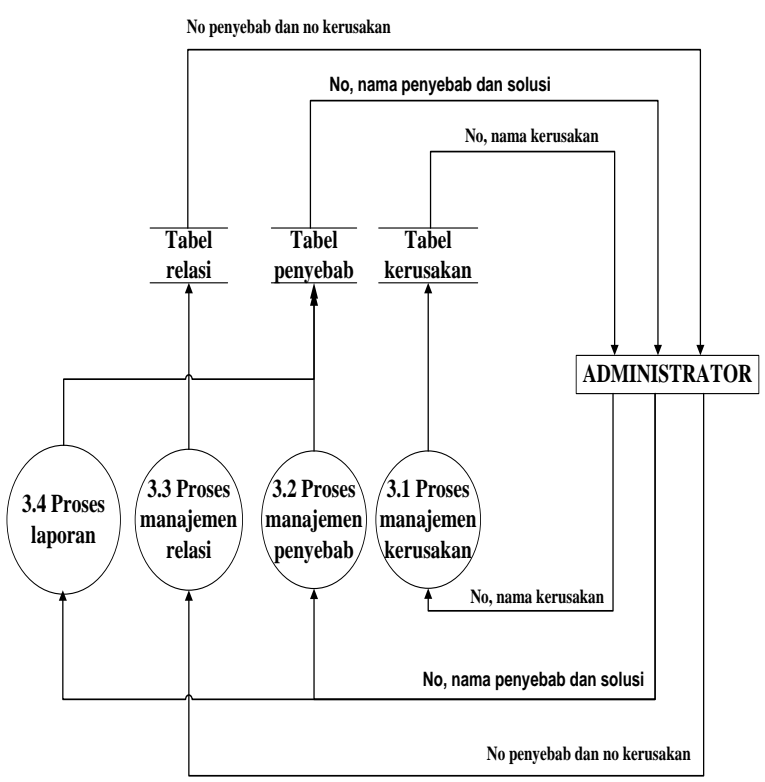

Gambar 5 Diagram level 1 Manajemen Database Sistem Pakar

\section{F. Perancangan Database}

Sistem pakar ini menggunakan database untuk menyimpan semua data yang akan ditampilkan dibuat dalam 7 tabel, yaitu:

1. Tabel Admin Tabel ini menyimpan user dan password yang digunakan oleh administrator untuk keperluan menambah, mengubah, dan menghapus data. 
2. Tabel Kerusakan Tabel ini menyimpan data kerusakan mesin. Tabel ini terdiri dari 4 field seperti pada tabel 2 .

3. Tabel penyebab Tabel ini menyimpan data penyebab dari setiap kerusakan. Tabel ini terdiri dari 2 field seperti pada tabel 3 .

4. Tabel relasi Tabel ini menyimpan data relasi antara kerusakan dan penyebab. Tabel ini terdiri dari 2 field seperti pada tabel 4 .

5. Tabel analisa_hasil Tabel ini menyimpan data dari user yang akan melakukan diagnosa kerusakan. Tabel ini terdiri dari 7 field seperti pada tabel 7

TABEL 1 TABEL ADMIN

\begin{tabular}{|l|l|l|l|}
\hline No & Attribut & Tipe Data & Keterangan \\
\hline 1 & Id & Integer(3) & Nomor admin \\
\hline 2 & nama & Varchar(225) & $\begin{array}{l}\text { Nama lengkap } \\
\text { admin }\end{array}$ \\
\hline 3 & email & Varchar(225) & Email admin \\
\hline 4 & kelamin & Varchar(8) & $\begin{array}{l}\text { Jenis kelamin } \\
\text { admin }\end{array}$ \\
\hline 5 & user & Varchar(25) & Nama admin \\
\hline 6 & password & Varchar(225) & $\begin{array}{l}\text { Password } \\
\text { admin }\end{array}$ \\
\hline
\end{tabular}

TABEL 2 TABEL KERUSAKAN

\begin{tabular}{|l|l|l|l|}
\hline No & Attribut & Tipe Data & Keterangan \\
\hline 1 & Kd_kerusakan & Char(4) & $\begin{array}{l}\text { Kode } \\
\text { kerusakan }\end{array}$ \\
\hline 2 & Nm_kerusakan & Varchar(60) & $\begin{array}{l}\text { Nama } \\
\text { kerusakan }\end{array}$ \\
\hline
\end{tabular}

TABEL 3 PENYEBAB

\begin{tabular}{|l|l|l|l|}
\hline No & Attribut & Tipe Data & Keterangan \\
\hline 1 & Kd_penyebab & Char(4) & $\begin{array}{l}\text { Kode } \\
\text { penyebab }\end{array}$ \\
\hline 2 & Nm_penyebab & Varchar(100) & $\begin{array}{l}\text { Nama } \\
\text { penyebab }\end{array}$ \\
\hline 3 & Solusi & Text & $\begin{array}{l}\text { Solusi } \\
\text { kerusakan }\end{array}$ \\
\hline
\end{tabular}

TABEL 4 TABEL RELASI

\begin{tabular}{|l|l|l|l|}
\hline No & Attribut & Tipe Data & Keterangan \\
\hline 1 & Kd_kerusakan & Char(4) & $\begin{array}{l}\text { Kode } \\
\text { kerusakan }\end{array}$ \\
\hline 2 & Kd_penyebab & Char(4) & $\begin{array}{l}\text { Kode } \\
\text { penyebab }\end{array}$ \\
\hline
\end{tabular}

TABEL 5 TABEL ANALISA_HASIL

\begin{tabular}{|l|l|l|l|}
\hline No & Attribut & Tipe Data & Lebar \\
\hline 1 & Id & Integer(4) & $\begin{array}{l}\text { Nomor urut } \\
\text { user }\end{array}$ \\
\hline 2 & Nama & Varchar(60) & Nama user \\
\hline 3 & Kelamin & $\begin{array}{l}\text { Enum(P \& } \\
\text { W) }\end{array}$ & $\begin{array}{l}\text { Jenis } \\
\text { kelamin } \\
\text { user }\end{array}$ \\
\hline 4 & Alamat & Varchar(100) & Alamat user \\
\hline 5 & Pekerjaan & Varchar(60) & $\begin{array}{l}\text { Pekerjaan } \\
\text { user }\end{array}$ \\
\hline 6 & Kd_kerusakan & Char(4) & $\begin{array}{l}\text { Hasil kode } \\
\text { kerusakan } \\
\text { user }\end{array}$ \\
\hline 7 & Noip & Varchar(60) & IP address \\
\hline
\end{tabular}

\section{PENGUJIAN DAN PEMBAHASAN}

Sistem pakar berbasis web ini dirancang untuk memberikan informasi yang dibutuhkan dan dapat melakukan diagnosa kerusakan. Karena sistem ini berbasis web, maka diperlukan web server untuk menjalankannya, dan database untuk menyimpan data

Sistem pakar ini menggunakan Apache2Triad sebagai webserver, MySQL sebagai database, PHP sebagai bahasa pemrograman serta Windows 7 Home Premium sebagai sistem operasi.

\section{A. Implementasi Rancangan}

Implementasi rancangan merupakan gambaran pelaksanaan dari sebuah aplikasi. Implementasi rancangan yang akan dibuat terbagi dua, yaitu implementasi rancangan user dan implementasi rancangan Administrator.

Berikut adalah gambar dari tampilan sistem pakar yang dibuat: 


\section{Menu Diagnosa}

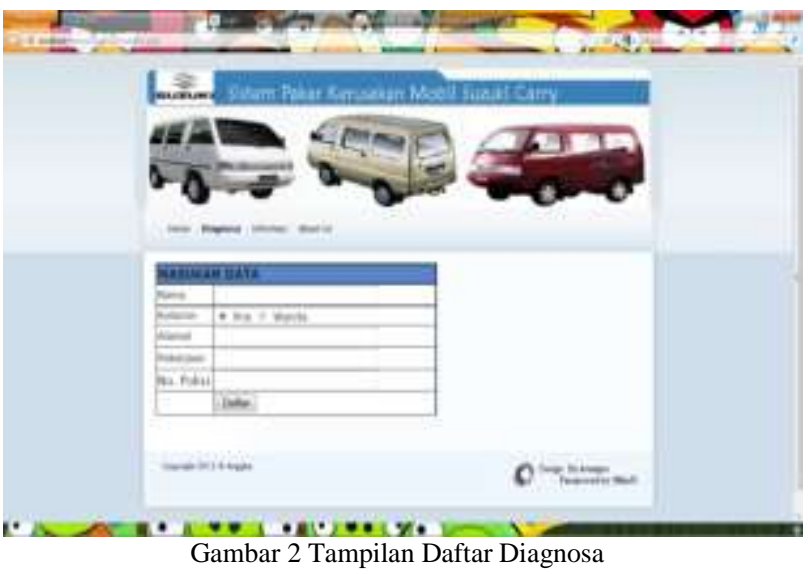

2. Menu Home Pakar

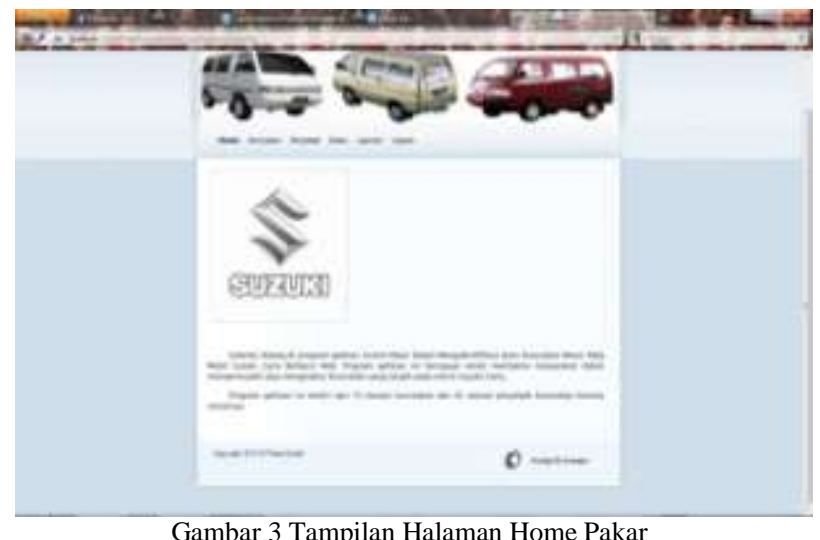

3. Menu Laporan

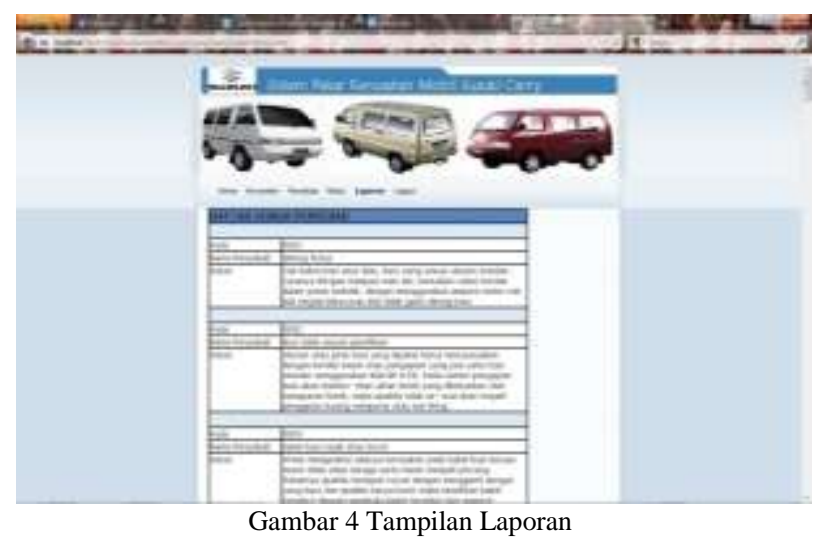

B. Pengujian Aplikasi

Tahapan ini merupakan tahapan testing. Pada tahapan ini, pengujian dilakukan pada 2 jenis akses yaitu, administrator dan user.

Sebagai contoh: Akses aplikasi oleh administrator.Bila admin memasukkan nama dan password yang salah. Maka sistem akan mencocokan data dengan database admin (seperti yang di tunjukkan pada gambar 5). Jika salah memasukkan nama/password, sistem akan memberikan pesan atau peringatan berupa password atau username yang anda masukkan salah, silahkan coba kembali.

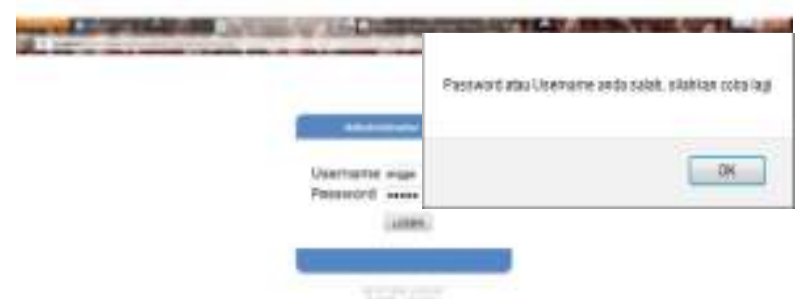

Gambar 5 Tampilan Pesan Admin Salah Memasukkan Nama/Password

\section{Pembahasan}

Seperti yang sudah dibahas pada bab 1, tentang mahalnya biaya kerusakan mesin yang harus dikeluarkan pemilik mobil bekas. Apalagi untuk Suzuki Carry dengan tipe karburator sudah tidak diproduksi lagi, sehingga menyebabkan biaya yang dikeluarkan pasti besar.

Untuk mengatasi permasalahan tersebut aplikasi sistem pakar ini membahas tentang bagaimana mengatasi kerusakan mesin Suzuki Carry. Dimana aplikasi ini membantu pemilik mobil Suzuki Carry untuk membantu memberikan solusi untuk mengatasi perbaikan mesin.

Contohnya user dengan keluhan seperti bahan bakar boros pada mobil Suzuki Carry dapat mengetahui gejala yang yang ditimbulkan dari kerusakan tersebut dengan mengakses aplikasi ini. Sehingga user dapat memperbaiki kerusakan mobilnya sendiri.

Berikut ini cara-cara yang bisa dilakukan user untuk mengatasi kerusakan bahan bakar boros.

- User dengan keluhan bahan bakar boros

1. Cara pertama yang dilakukan adalah dengan masuk keprogram aplikasi sistem pakar kemudian memilih menu diagnosa kerusakan (gambar 6).

2. Setelah itu user memasukkan nama, jenis kelamin, alamat dan pekerjaan, no. polisi untuk proses daftar. Selanjutnya, setelah user melakukan proses daftar maka akan muncul keluhan berupa bahan bakar boros (gambar 7).

3. Selanjutnya akan muncul pertanyaan terkait keluhan yang user pilih (gambar 8).

4. Setelah user menjawab pertanyaan terkait keluhan bahan bakar boros. Maka akan muncul hasil analisa akhir (gambar 9). 

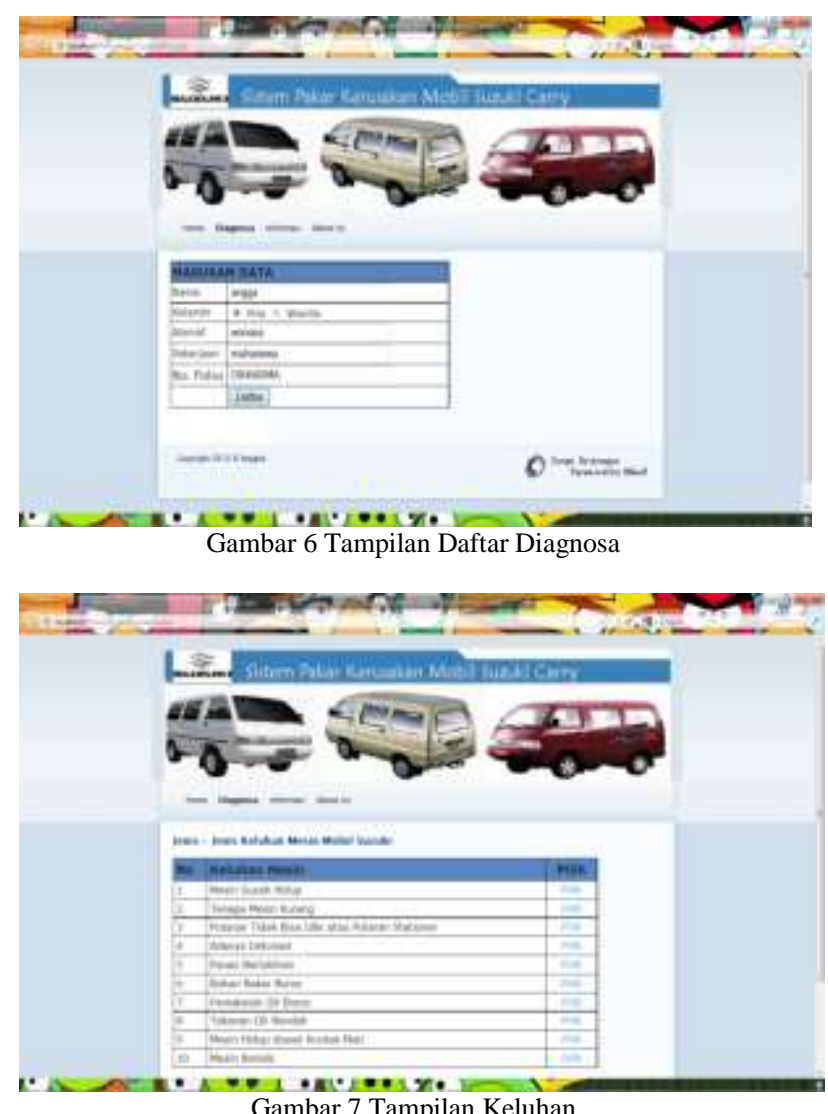

Gambar 7 Tampilan Keluhan

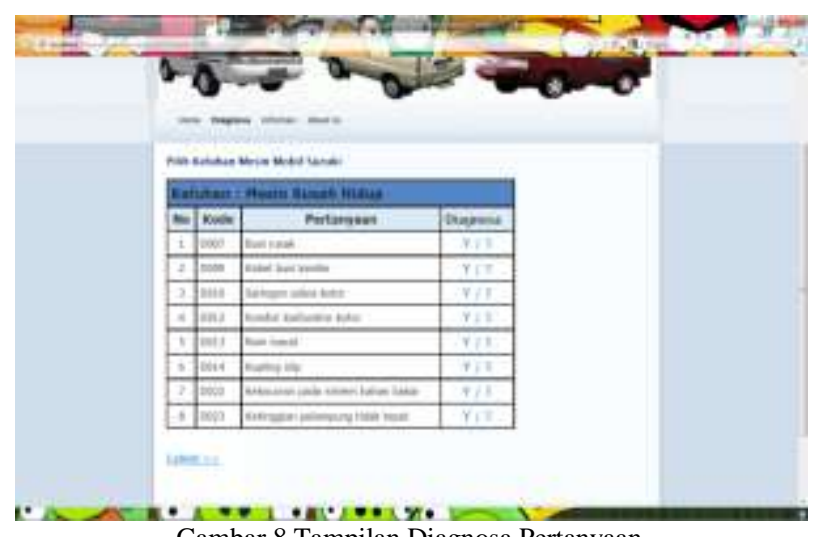

Gambar 8 Tampilan Diagnosa Pertanyaan

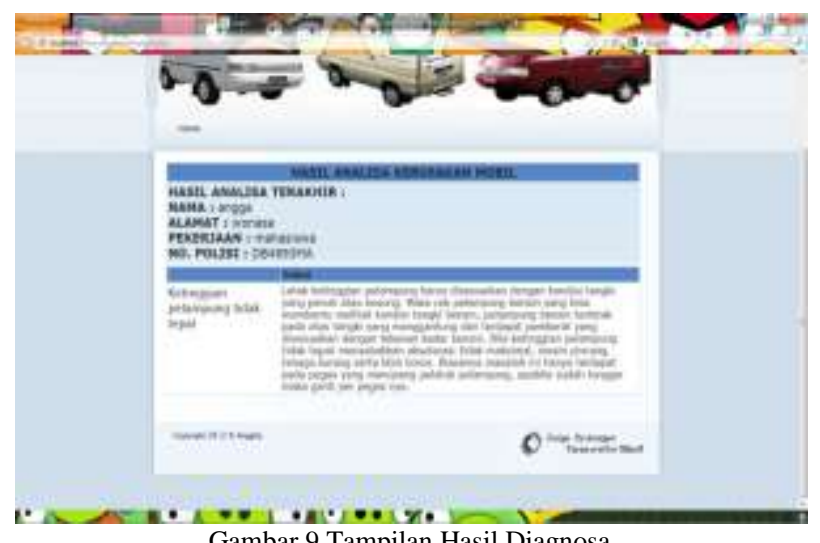

Gambar 9 Tampilan Hasil Diagnosa

\section{Kesimpulan}

Berdasarkan implementasi dan uji coba aplikasi yang dibangun, penulis dapat menarik beberapa kesimpulan, yaitu:

1. Sistem pakar ini dapat digunakan untuk mendiagnosa dan menemukan solusi dari kerusakan mobil Suzuki Carry.

2. Sistem pakar berbasis web memudahkan pengguna/user. 


\section{DAFTAR PUSTAKA}

[1] F. R. Artanti, Perancangan dan Pembuatan Sistem Pakar Hama dan Pengendaliannya untuk Tanaman Holtikultura, Skripsi. Universitas Kristen Petra, Surabaya, 2004.

[2] P. Ballard, Sams Teach Yourself Ajax, Javascript, and PHP All in One. Sams Publishing, United States of America, 2009

[3] A. S. Broto, Perancangan dan Implementasi Sistem Pakar Untuk Analisa Penyakit Dalam, Skripsi, Universitas Dipenegoro, Semarang, 2010.

[4] T. Converse, and J. Park, with C. Morgan, PHP5 and MySQL® Bible,Wiley Publishing, Inc, Indianapolis, 2004.

[5] J. Durkin, Expert System Design and Development, Prentice Hall Inc, New Jersey, 1994.

[6] J. Gilmore, Beginning PHP and MySQL: From Novice to Professional, Fourth Edition. Springer Science+Business Media, LLC, United States of America, 2010.

[7] S. Hartati, S. Iswanti, Sistem Pakar dan Pengembangannya, Penerbit Graha Ilmu, Yogyakarta, 2008.

[8] J. P. Ignizio, Introduction To Expert Systems: The Development and Implementation Of Rule-Based Expert Systems, McGrawHill, Inc, 1991.

[9] A. Kadir, Mudah Mempelajari Database MySQL. Penerbit Andi Yogyakarta, 2010.

[10] Kusrini, S.Kom. Sistem Pakar, Teori dan Aplikasi, Penerbit Andi, Yogyakarta, 2006.

[11] B. Pfaffenberger, M. Steven, Schafer, C. White, B. Karow, $H T M L, X H T M L$, and CSS Bible, $3^{\text {rd }}$ Edition. Wiley Publishing, Inc, Indianapolis, 2004.

[12] B. Raharjo, I. Heryanto, R.K. Enjang, Modul Pemrograman Web(HTML, PHP \& MYSQL). Penerbit Modula, Bandung, 2010.

[13] Siswanto Kecerdasan Tiruan, Edisi Pertama, Penerbit Graha Ilmu, Yogyakarta, 2005.

[14] E. Turban, Decision Support Systems and Expert Systems. Prentice Hall International Inc, USA, 1995.

[15] E. Turban, Aronson, J. Liang, Ting-Peng. Decision Support Systems and Intelligent Systems (Sistem pendukung keputusan dan sistem cerdas), Penerbit Andi, Yogyakarta, 2005. 